\title{
Developing Grades 1-6 Teachers' English Communication Skills and English Teaching Techniques Using Training and Coaching in Lop Buri Thailand
}

\author{
Kongsoongnoen, K. ${ }^{1}$, Watcharapanyawong, S. ${ }^{1}$ \\ ${ }^{1}$ Department of English, Faculty of Humanities and Social Sciences, Thepsatri Rajabhat \\ University, Lop Buri, Thailand
}

Corresponding email: kat_008w@yahoo.com

\begin{abstract}
The purposes of this research were (1) to develop English for communication skills for grades 1-6 teachers, 2) to develop the teachers' English teaching skills, and (3) to increase the students' English Achievement. The participants were 15 teachers with no degree in English from 14 small size primary schools in Lop Buri province Thailand. The 30 hour English communication and 30 hour English teaching training were provided to the teachers. School visits with Coaching approach was applied for support their teaching at schools as well as teaching materials the teachers needed. A questionnaire comprising both open and closedended questions was used to evaluate the teachers' teaching. The interview questions and the teachers' reflection form were conducted for collecting their perception on the project, percentage and mean were applied to analyze quantitative data whereas content analysis was conducted for qualitative data. The findings showed that the teachers' English for communication skills and English teaching skills were increased. The teachers' English communication skills and their teaching skills were higher than before whereas their teaching application was at a medium level. Fifty percent of the teachers' teaching skills were at a high level while $20 \%$ barely applied their teaching experience they received from the training and coaches. One hundred percent of the teachers agreed that the project was the most useful for them and many highlighted that they'd immensely learned teaching techniques and just realized that they could make their English class interesting for the students because they felt confident after the training. However, a few teachers had no chance to teach English because their schools had someone qualified to teach instead.
\end{abstract}

Keywords: Grades 1-6 teachers; English communication skills; English teaching techniques; training and coaching

DOI: http://dx.doi.org/10.20961/ijpte.v1i2.15028 


\section{INTRODUCTION}

English language has been taught through different approaches in every school in Thailand for almost a hundred years, however, the English achievement of Thai students is still not satisfied. Compared to other school subjects, the students' English score has been almost at the lowest level (Problems of Teaching English Language, 2016). Only 10\% of Thai people can use English for communication (English Language Teachers, Educational Critics, 2015). Sumrit Sukruanfrit (1999) stated that lacking teaching skills and a meaningful learning environment were important causes of the students' low achievement. Similarly, Kanya Wuttiketpaiboon (1999) found that English teachers in secondary school in Nakhon Ratchasima province requested training on teaching techniques, teaching materials, and language assessment. Similarly, toward English were problematic. Accordingly, teachers have a crucial role in developing the students' ability. Therefore, these teachers need to be knowledgeable and skillful in both English contents and teaching methodologies.

The research study examined the situations, problems, and needs in teaching English of 170 grades 1-6 teachers in five provinces located in the five provinces in the central region of Thailand: Lop Buri, Sing Buri, Saraburi, Suphan Buri, and Ang-Thong in 2016 revealed that only $25.29 \%$ of the teachers received a bachelor degree in English. Most teachers mentioned that lacking teaching methodologies, contents, and skills in English were of concern when teaching English, therefore, they needed teaching English training especially the English teaching methodologies and English skills. The researcher accordingly aimed to develop grades 1-6 teachers' english communication skills and english teaching techniques using training and coaching in Lop buri Thailand in order to support and help improve the English teachers and eventually the students' English achievement.

\section{PURPOSE OF THIS STUDY}

The study was designed to1 ) to develop English for communication skills for grades 1-6 teachers, 2) to develop English teaching skills, and (3) to increase the students' English Achievement. The focus of the study was to support English language teachers who had no degree in English and to develop the students' English achievement.

\section{METHODOLOGY}

This study was a mixed method research including both quantitative and qualitative methodology. The research population consisted of 14 teachers from 14 primary schools who taught English in grades 1 - 6 in Lop Buri province in 2017. The research instruments comprised 1) the prestest and posttest for measuinge the teachers' English Communication and Teaching skills and 2) the interview questionnaire, and 30 the teachers' reflection form. Mean score was 
applied to analyze quantitative data whereas content analysis was conducted for qualitative data.

\section{RESULT}

Considering the teachers' English for communication skills, the reserach findings showed that $100 \%$ of the teachers' English for communication skills before the training were poor $(\bar{X}=3.18)$. The teachers' post test score on English for communication skills was at a good level $(\bar{X}=7.12)$. The score of the individual contents were shown in Table 1.

Table 1 Teachers’ English for communication skills based on the contents

\begin{tabular}{|c|c|c|c|c|c|}
\hline \multicolumn{2}{|r|}{ Items } & \multirow{2}{*}{$\begin{array}{c}\text { Pretest } \\
4.35\end{array}$} & \multirow{2}{*}{$\begin{array}{c}\text { Levels } \\
\text { Poor }\end{array}$} & \multirow{2}{*}{$\begin{array}{c}\text { Posttest } \\
8.35\end{array}$} & \multirow{2}{*}{$\begin{array}{c}\text { Levels } \\
\text { Very Good }\end{array}$} \\
\hline 1 & Self-Introduction & & & & \\
\hline 2 & Personal \& Family Information & 3.57 & Poor & 7.71 & Good \\
\hline 3 & Asking \& Giving Information & 3.07 & Poor & 7.21 & Good \\
\hline 4 & Phonetic Symbols and Sounds & 2.93 & Poor & 6.64 & Fair \\
\hline 5 & Stress Patterns in Words & 2.14 & Poor & 5.64 & Fair \\
\hline 6 & Going Shopping & 3.36 & Poor & 7.57 & Good \\
\hline 7 & Local Geography & 2.00 & Poor & 6.57 & Fair \\
\hline \multirow[t]{2}{*}{8} & Basic Grammar & 4.00 & Poor & 7.50 & Good \\
\hline & $\bar{X}$ & 3.18 & Poor & 7.12 & Good \\
\hline
\end{tabular}

Table 1 showed that the teachers' posttest of English for communication ability ( $\bar{X}=7.12$ or $71.20 \%)$ was higher than the pretest ( $\bar{X}=3.18$ or $30.80 \%)$. When considered by descending order, the teachers' pretest score on Self-Introduction ability ( $\bar{X}=4.35$ or $43.50 \%$ ) and Basic Grammar ability ( $\bar{X}=4.00$ or $40 \%$ ) were the highest respectively, whereas, the teachers' postest score on Self-Introduction and Personal \& Family Information ( $\bar{X}=8.35$ or $83.50 \%$ ). were the highest respectively. The pretest score on the Local Geography ( $\bar{X}=2.00$ or $20 \%$ ). was the lowest as well as the posttest score of Stress Patterns in Words ( $\bar{X}=5.56$ or $55.60 \%)$.

Table 2 Individual pretest score of Teachers' English for communication skills

\begin{tabular}{|c|c|c|c|c|c|c|c|c|c|c|c|c|c|c|c|}
\hline \multicolumn{2}{|r|}{ Items / Teachers } & 1 & 2 & 3 & 4 & 5 & 6 & 8 & 9 & 10 & 11 & 12 & 13 & 14 & $\bar{X}_{110}$ \\
\hline 1 & Self-Introduction & $\overline{4}$ & $\overline{7}$ & $\overline{2}$ & $\overline{3}$ & $\overline{5}$ & $\overline{3}$ & $\overline{4}$ & $\overline{5}$ & $\overline{4}$ & $\overline{5}$ & $\overline{4}$ & $\overline{5}$ & $\overline{5}$ & 4.35 \\
\hline 2 & $\begin{array}{l}\text { Personal \& Family } \\
\text { Information }\end{array}$ & 3 & 7 & 2 & 3 & 3 & 4 & 3 & 4 & 3 & 4 & 3 & 3 & 4 & 3.57 \\
\hline 3 & Asking \& Giving Information & 3 & 6 & 2 & 2 & 3 & 3 & 2 & 3 & 3 & 3 & 4 & 3 & 3 & 3.07 \\
\hline 4 & $\begin{array}{l}\text { Phonetic Symbols and } \\
\text { Sounds }\end{array}$ & 4 & 5 & 2 & 2 & 2 & 2 & 2 & 3 & 2 & 3 & 3 & 3 & 4 & 2.93 \\
\hline 5 & Stress Patterns in Words & 2 & 4 & 2 & 1 & 1 & 2 & 1 & 2 & 3 & 2 & 2 & 3 & 2 & 2.14 \\
\hline 6 & Going Shopping & 3 & 6 & 3 & 4 & 3 & 3 & 2 & 3 & 3 & 3 & 4 & 3 & 3 & 3.36 \\
\hline 7 & Local Geography & 2 & 5 & 2 & 1 & 2 & 2 & 1 & 2 & 2 & 2 & 2 & 1 & 2 & 2.00 \\
\hline
\end{tabular}




\begin{tabular}{|c|c|c|c|c|c|c|c|c|c|c|c|c|c|c|c|}
\hline 8 & Basic Grammar & 3 & 7 & 4 & 5 & 4 & 3 & 3 & 4 & 4 & 5 & 3 & 3 & 4 & 4.00 \\
\hline & $\bar{X}$ & 3 & $\begin{array}{l}5 . \\
87\end{array}$ & 2. & 2. & $\begin{array}{l}2 . \\
87\end{array}$ & $\begin{array}{l}2 . \\
75\end{array}$ & $\begin{array}{l}2 . \\
25\end{array}$ & $\begin{array}{l}3 . \\
25\end{array}$ & 3 & $\begin{array}{l}3 . \\
37\end{array}$ & $\begin{array}{l}3 . \\
12\end{array}$ & 3 & $\begin{array}{l}3 . \\
37\end{array}$ & 3.18 \\
\hline
\end{tabular}

Table 2 highlighted the individual pretest score of the teacher's ability in English communication skills as a whole which was at a poor level $(\bar{X}=3.18)$. The teachers' highest score was on Self-Introduction (4.35), whereas Local Geography was the lowest (2.00). When considered by contents and by descending order, there were Self-Introduction $(\bar{X}=4.35)$, Basic Grammar $(\bar{X}=4.00)$, Personal \& Family Information ( $\bar{X}=3.57)$, Going Shopping $(\bar{X}=3.36)$, Asking \& Giving Information ( $\bar{X}=3.07)$, Phonetic Symbols And Sounds ( $\bar{X}=2.93)$, Stress Patterns In Words $(\bar{X}=2.14)$, and Local Geography $(\bar{X}=2.00)$ respectively. Only one teacher passed $50 \%$ of the test.

Table 3 Individual posttest score of Teachers’ English for communication skills

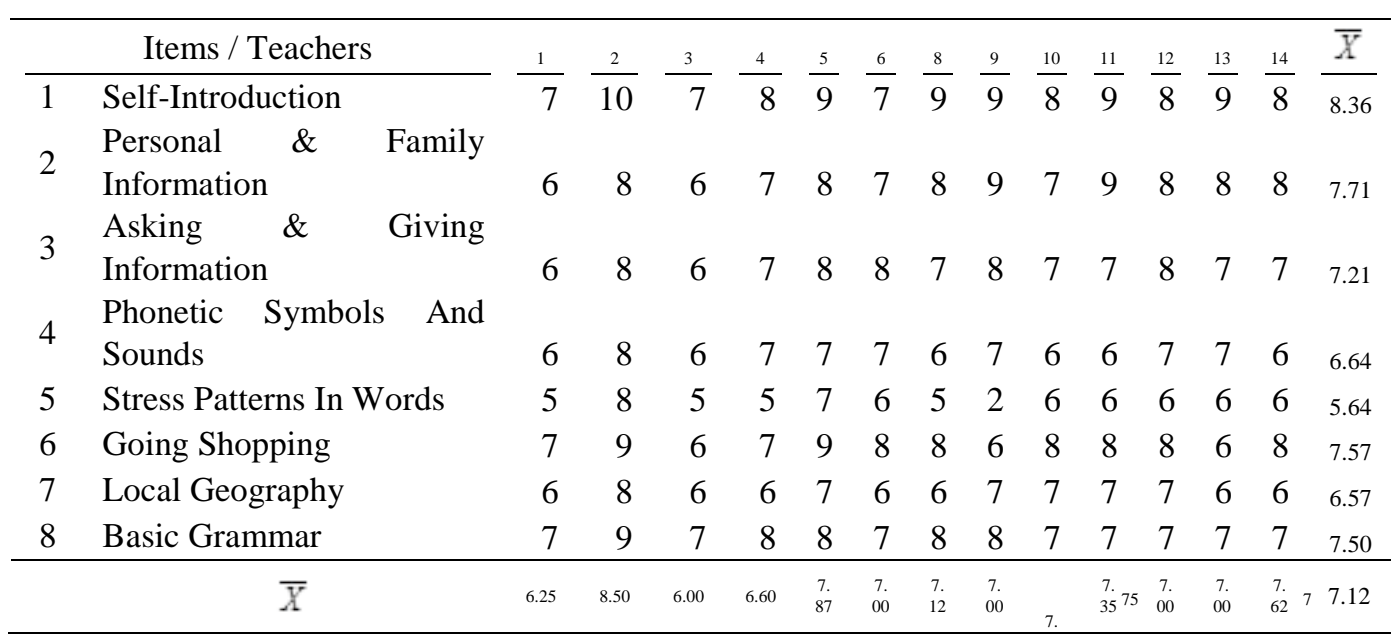

Table 3 highlighted the individual posttest score of the teacher's ability in English communication skills as a whole which was at a goog level $(\bar{X}=7.12)$. The teachers' highest score was on Self-Introduction ( $\bar{X}=8.36)$, whereas Stress Patterns in Words was the lowest $(\bar{X}=5.64)$. When considered by contents and by descending order, there were Self-Introduction $(\bar{X}=8.36)$, Personal \& Family Information ( $\bar{X}=7.71)$, Going Shopping $(\bar{X}=7.57)$, Basic Grammar $(\bar{X}=7.50)$, Asking \& Giving Information $(\bar{X}=7.21)$, Phonetic Symbols and Sounds $(\bar{X}=$ 6.64), Local Geography ( $\bar{X}=6.54)$, and Stress Patterns In Words $(\bar{X}=5.64)$ respectively. All teacher passed $50 \%$ of the test.

Table 4 Pretest and posttest scores on Teachers’ Teaching skills

\begin{tabular}{|c|c|c|c|c|c|}
\hline \multicolumn{2}{|r|}{ Items } & Pretest & Levels & Posttest & Levels \\
\hline 1 & Teaching Listening & 3.78 & Poor & 6.86 & Fair \\
\hline 2 & Teaching Speaking & 4.57 & Poor & 7.92 & Good \\
\hline 3 & Teaching Reading & 4.50 & Poor & 7.21 & Good \\
\hline 4 & Teaching Writing & 5.00 & Fair & 7.71 & Good \\
\hline
\end{tabular}




\begin{tabular}{lllllc}
5 & Teaching Vocabulary & 4.86 & Poor & 8.14 & Very Good \\
6 & Teaching Grammar & 5.29 & Poor & 7.79 & Good \\
7 & Classroom English & 3.29 & Poor & 6.64 & Fair \\
8 & Songs \& Games & 4.71 & Poor & 8.00 & Very Good \\
\hline & & 4.50 & Poor & 7.54 & Good \\
\hline
\end{tabular}

Table 4 showed that the teachers' posttest of teaching skills ( $\bar{X}=7.54$ or $75 \%$ ) as a whole ( $\bar{X}=7.54$ or $75 \%)$ were higher than the pretest ( $\bar{X}=4.50$ or $45 \%)$. When considered the posttest by descending order, the teachers' postest score on teaching vocabulary ( $\bar{X}=8.14$ or $81 \%$ ) and Classroom English $(\bar{X}=8.00$ or 50 $\%)$ were the highest respectively, whereas, the teachers' pretest score on teaching grammar ( $\bar{X}=5.29$ or $53 \%$ ) and teaching writing ( $\bar{X}=5.00$ or $50 \%$ ) were the highest respectively. The pretest score classroom English was the lowest $(\bar{X}=$ 6.64 or $66 \%$ ) whereas Teaching Grammar was the highest. In particular, teaching vocabulary and songs \& games was dramatically increased from Poor to Very Good.

Table 5 Individual pretest score of Teachers’ Teaching skills

\begin{tabular}{|c|c|c|c|c|c|c|c|c|c|c|c|c|c|c|c|c|}
\hline & Items / Teachers & & & & 4 & 5 & 6 & 7 & 8 & 9 & 10 & 11 & 12 & 13 & 14 & $\bar{X}$ \\
\hline 1 & Teaching Listening & 2 & 6 & 5 & 3 & 4 & 5 & 2 & 4 & 3 & 4 & 3 & 3 & 4 & 5 & 3.79 \\
\hline 2 & Teaching Speaking & 3 & 7 & 6 & 3 & 3 & 5 & 3 & 6 & 4 & 5 & 4 & 3 & 6 & 6 & 4.57 \\
\hline 3 & Teaching Reading & 4 & 7 & 5 & 4 & 4 & 4 & 4 & 5 & 4 & 4 & 4 & 4 & 5 & 5 & 4.50 \\
\hline 4 & Teaching Writing & 4 & 8 & 6 & 4 & 5 & 4 & 4 & 5 & 4 & 5 & 5 & 5 & 6 & 5 & 5.00 \\
\hline 5 & Teaching Vocabulary & 5 & 6 & 6 & 5 & 5 & 5 & 3 & 5 & 5 & 5 & 5 & 3 & 5 & 5 & 4.86 \\
\hline 6 & Teaching Grammar & 4 & 7 & 6 & 5 & 6 & 6 & 4 & 6 & 5 & 5 & 5 & 4 & 5 & 6 & 5.29 \\
\hline 7 & Classroom English & 3 & 6 & 5 & 3 & 2 & 4 & 1 & 3 & 3 & 3 & 3 & 3 & 3 & 4 & 3.29 \\
\hline 8 & Songs \& Games & 4 & 7 & 6 & 5 & 4 & 5 & 3 & 4 & 5 & 5 & 4 & 5 & 4 & 5 & 4.71 \\
\hline & $\bar{X}$ & $\begin{array}{l}3 . \\
63\end{array}$ & $\begin{array}{l}6 . \\
75\end{array}$ & $\begin{array}{l}5 . \\
63 .\end{array}$ & $\begin{array}{l}4.0 \\
00\end{array}$ & $\begin{array}{l}4 . \\
13\end{array}$ & $\begin{array}{l}4.9 \\
75\end{array}$ & $\begin{array}{l}3 . \\
00\end{array}$ & $\begin{array}{l}4.5 \\
75\end{array}$ & $\begin{array}{l}4.4 \\
13\end{array}$ & ${ }_{5}^{4}$ & 13. & $\begin{array}{l}3 . \\
75\end{array}$ & $\begin{array}{l}4 . \\
75\end{array}$ & $\begin{array}{l}5 . \\
12\end{array}$ & 4.50 \\
\hline
\end{tabular}

Table 5 presented the individual pretest score of the teacher's skills in Teaching English as a whole which was at a poor level $(=4.50)$. The teachers' highest score was on Teaching Grammar ( $\bar{X} 5.29$ ), whereas Classroom English was the lowest (3.29). When considered by contents and by descending order, there were Teaching Grammar ( $\bar{X}=5.29)$, Teaching Writing $(\bar{X}=5.00)$, Teaching Vocabulary ( $\bar{X}=4.86)$, Songs \& Gamrs $(\bar{X}=4.71)$, Teaching Speaking $(\bar{X}$ =4.57), Teaching Reading ( $\bar{X}=4.50)$, Teaching Listening ( $\bar{X}=3.79$ ), and Classroom English $(\bar{X}=3.29)$ respectively. Only 2 teachers passed $50 \%$ of the test.

Table 6 Individual posttest score of Teachers’ Teaching skills

\begin{tabular}{|c|c|c|c|c|c|c|c|c|c|c|c|c|c|c|c|c|}
\hline & Items / Teachers & 1 & 2 & 3 & 4 & 5 & 6 & 7 & 8 & 9 & 10 & 11 & 12 & 13 & 14 & $\bar{X}$ \\
\hline \multirow{2}{*}{1} & Tonching J ictoning & & 1 & & & & & & & & & & & & & \\
\hline & 1 eacning Listening & 7 & 0 & 7 & 8 & 9 & 7 & 9 & 9 & 8 & 9 & 8 & 9 & 8 & 9 & 8.36 \\
\hline 2 & Teaching Speaking & 6 & 8 & 6 & 7 & 8 & 7 & 8 & 9 & 7 & 9 & 8 & 8 & 8 & 9 & 7.71 \\
\hline
\end{tabular}




\begin{tabular}{cllllllllllllllll}
3 & Teaching Reading & 6 & 8 & 6 & 7 & 8 & 8 & 7 & 8 & 7 & 7 & 8 & 7 & 7 & 7 & 7.21 \\
4 & Teaching Writing & 6 & 8 & 6 & 7 & 7 & 7 & 6 & 7 & 6 & 6 & 7 & 7 & 6 & 7 & 6.64 \\
5 & Teaching Vocabulary & 5 & 8 & 5 & 5 & 7 & 6 & 5 & 2 & 6 & 6 & 6 & 6 & 6 & 6 & 5.64 \\
6 & Teaching Grammar & 7 & 9 & 6 & 7 & 9 & 8 & 8 & 6 & 8 & 8 & 8 & 6 & 8 & 8 & 7.57 \\
7 & Classroom English & 6 & 8 & 6 & 6 & 7 & 6 & 6 & 7 & 7 & 7 & 7 & 6 & 6 & 7 & 6.57 \\
8 & Songs \& Games & 7 & 9 & 7 & 8 & 8 & 7 & 8 & 8 & 7 & 7 & 7 & 7 & 7 & 8 & 7.5 \\
\hline \multirow{X}{*}{} & 6. & 8. & 6 & 6. & 7. & 7 & 7. & 7 & 7 & 7 & 7. & & & 7. & 7.12 \\
& 5 & 5 & 6 & 6 & 8 & 7 & 1 & 7 & 7 & 3 & 3 & 7 & 7 & 6 & 7.12 \\
\hline
\end{tabular}

Table 6 revealed the individual postest score of the teacher's skills in Teaching English as a whole which was at a good level $(=7.12)$. The teachers' highest score was on Teaching Listening ( $\bar{X}$ 8.36), whereas Classroom English was the lowest (6.57). When considered by contents and by descending order, there were Teaching Listening ( $\bar{X}=8.36)$, Teaching Speaking $(\bar{X}=7.71)$, Teaching Grammar ( $\bar{X}=7.57)$, Teaching Reading ( $\bar{X}=7.21)$, Teaching Writing ( $\bar{X}=6.64)$, Classroom English ( $\bar{X}=6.57)$, and Teaching Vocabulary $(\bar{X}=5.64)$, respectively. All teachers passed $50 \%$ of the test.

The content analysis of the open - ended interview questions and teachers' reflections asking about teachers' before and after the training and coaching indicated that most teachers were satisfied with the development process and realized how to teach English properly. Considering about their English communication skills, they were more confident to use English to communicate and teach than before. Their teaching skills also were developed and able to teach English more effectively. According to the coaches' classroom visit, they reflected that $50 \%$ of the teachers participated in the project applied their knowledge and experience into their classes whereas two teachers didn't because the schools had the preservice teachers to practice teaching English, one had got a serious sickness, one moved to a new school, and one was going to retire in September.

When asking the teachers about the matrials produced by the preservice teachers the researchers assigned to work with the teachers based on the English standards (games, charts, worksheet, cards, picture, etc.) the teachers and the directors were highly satisfied with them. The materials became the tools to make the students learn better and more effective and they think providing learning materials were very useful for the students. The feedback from the students strongly showed that most sudents enjoyed the variety of learning English from the teachers and their attitude towards English had positicely enhanced. The teachers mentioned that most students looked forwards to learning English.

\section{DISCUSSION}

According to the research results, the followings are discussions covering the two main aspects.

The results of the pretest and posttest of the teachers' English for communication skills pointed out that all teachers' posttest score $(\bar{X}=3.18)$ was dratically higher 
than the pretest's scores $(\bar{X}=7.12)$. The interview analysis showed that all teachers satisfied with the training, most requested more training to fulfil their English skills especially learning grammar and pronuciation. They felt more confident to teach English after this training.

Similaly, the posttest score of the teachers' English teaching skills ( $\bar{X}=4.50$ ) was higher than the pretest score after the training $(\bar{X}=7.54)$. The interview analysis indicated that all teachers satisfied with the teaching training because it strongly helped improve their teaching skillsThey felt more confident to teach English after this training. The teachers used more English, various teaching activities, and materials when teaching. Doing this, English lessons became interesting for the students.

The students' achievement hasn't shown yet in this period, but the students' positive attitude toward English. This result would take another year to complete.

Regarding the results of the teachers' Communication skills and teaching skills, lacking English contents and teaching skills immensely caused the students' English achievement. Most teachers reflected that they just followed the text when teaching or ignored English classes. The teachers' qualifications have dbecome problematic and produce low achievement for years. Importantly, teachers need to be able to apply learning activities to encourage and build up students' positive attitude towards English because people normally learn better when they feel positive about it (Harmer, 2015).

\section{Suggestion}

According to the research findings, the suggestions on developing teachers teaching English without a degree in English and teaching English are below:

1. Since the government is unable to produce qualified English teachers to support schools immediately, therefore, the best things to promote English learning is to develop available teachers to be able to teach effectively through intensive training and coaching organized by teacher professional development organizations.

2. The training curriculum for the unqualified teachers should thoroughly include English contents and skills, teaching methodology, teaching materials, and evaluation.

3. The government should support necessary learning materials and technology such as supplementary books, learning programs, internet, etc. to help promote the students' English learning.

4. Teachers should organize various activities and build the English learning atmosphere to interest the students and change their attitude towards English (Khajloo, 2013).

5. The government immensely has to set up a plan to produce adequate qualified English teachers to teach English effectively and then send them out to all schools. 


\section{Future Research}

1. There should be future research on developing teaching English for Grades 1-6 Teachers in a larger area or all regions of Thailand in order to get more insight and implement the findings to others.

2. There should be future research comparing the students' English achievement of English teachers whose degree is English and non-English.

3. Based on the teachers' needs, future research may be conducted on training teaching English emphasizin on other areas of English teaching.

\section{CONCLUSION}

Teachers' qualifications are critical issues for the students' English achievement. What happen to the students when teachers without degree in English have to teach English? Certainly, they are not confident in English contents and skills, they don't know how to teach and evaluate the students' learning. Consequently, they are seriously in need of intensive professional development, firstly in the English contents and skills to establish their confidence in English, and then teaching methodology particularly with the four main skills, listening, speaking, reading, and writing. To be able to teach English effectively, they require understanding about learning evaluation and using materials as well. Evidently, the factors affecting the students' learning mostly are caused by the teachers' limitations.

The research findings point out the significant solution for enhancing students' English achievement by putting the prioriy on improving the teachers' English skills and teaching methology. The process of producting English teachers needs to be effective both in quantity and quality so that to a sustainable development of English proficiency of Thai people's in the future.

\section{ACKNOWLEDGEMENT}

Foremost, we would like to express our sincere gratitude to all teachers who willingly dedicated their time to participate in the very long training. Thanks for their patience and time spent to learn and practice English skills and teaching methodology.

We would also like to thank the coaches from Thepsatri Rajabhat University, Ms. Sasiwimon Sutthisan, Ms. Pichitra Iamsamai, Ms. Sasiluk Rodphothong, Ms. Benjapon Nualprasert, Ms. Wunwisa Punkhoom, Mr. Pornthep Kuchamat, and Dr. Somchai Watcharapunyawong.

Finally, our sincere thanks also goes to the office of Higher Educaion Commission, Thialand who supported the budget for developing English teachers who have no degree in English. 


\section{REFERENCES}

English teachers...educational crisis of Thailand." (2015). Retrieved from http://th.jobsdb.com/thth/articles

Harmer, J. (2015). The Practice of English Language Teaching. $5^{\text {th }}$ edition. Slovakia: Pearson.

Khajloo, A. I. (May, 2013). Problems in Teaching and Learning English for Students. International Journal of Engineering Research and Development e-ISSN: 2278-067X, p-ISSN: 2278800X, www.ijerd.com Volume 7, Issue 3, PP. 56-58

Sumrit Sukruangrit. Teachers must reform curriculum \& learning process: Chaing Rai Teachers. Year 33, vol. 180, (June, 1999): 4-6.

Wuttikietpaiboon, K. (1999). The Report of the study of teaching situations, problems, and needs of the secondary school English teachers in Nakhon Ratchasima province.Thailand: the office of Nakhon Ratchasima provincial General Education.

Yassi, B. (June, 2015). Challenges of Teaching English Language to English Language Learners at Private Universities in Jordan Arab World English Journal (AWEJ). vol.6. No.2. 